\title{
PENERAPAN MODEL SAINS TEKNOLOGI MASYARAKAT (STM) UNTUK MENINGKATKAN KETERAMPILAN BERPIKIR KREATIF SISWA KELAS V DI SEKOLAH DASAR
}

\author{
Suko Pratomo ${ }^{1}$, Tati Sumiati ${ }^{2}$, Risqa Mursilah ${ }^{3}$ \\ e-mail : sukopratomo60@gmail.com, sumiatitati5@gmail.com, \\ risqa.mursilah95@student.upi.edu
}

\begin{abstract}
ABSTRAK
Penelitian ini dilatarbelakangi oleh rendahnya keterampilan berpikir kreatif siswa kelas VB SDN Cikampek Timur I, hal ini dibuktikan dengan pengujian instrumen soal keterampilan berpikir kreatif yang mencakup lima indikator keterampilan berpikir kreatif. Keterampilan berpikir kreatif adalah salah satu keterampilan yang harus dimiliki oleh siswa. Salah satu model pembelajaran yang dapat digunakan dalam meningkatkan keterampilan berpikir kreatif siswa adalah dengan menerapkan model pembelajaran Sains Teknologi Masyarakat (STM) yang di dalamnya terdapat lima fase atau tahapan. Subjek penelitian yang digunakan dalam penelitian ini adalah siswa kelas VB SDN Cikampek Timur I yang berjumlah 20 siswa. Adapun tujuan dilakukannya penelitian ini adalah: 1)Aktivitas belajar siswa kelas VB SDN Cikampek Timur I dengan menggunakan model Sains Teknologi Masyarakat (STM) dalam pembelajaran IPA; 2)Peningkatan keterampilan berfikir kreatif siswa kelas VB SDN Cikampek Timur I setelah menggunakan model Sains Teknologi Masyarakat (STM) dalam pembelajaran IPA. Metode penelitan yang digunakan adalah penelitian tindakan kelas. Penelitian ini dilakukan sebanyak 3 siklus dengan hasil peningkatan yang signifikan pada persentase Ketuntasan Belajar Siswa Klasikal (KBSK) setiap siklusnya. Hasil nilai rata-rata $N$-Gain keterampilan berpikir kreatif siswa kelas VB SDN Cikampek Timur I termasuk kedalam kategori sedang pada setiap siklusnya. Hal ini dibuktikan dengan adanya perbandingan skor pretest dan posttest yang mencakup lima indikator keterampilan berpikir kreatif dan indikator pembelajaran. Adanya peningkatan pada hasil posttest setiap siklusnya dipengaruhi oleh aktivitas siswa yang mengalami peningkatan yang signifikan pada setiap siklusnya. Berdasarkan hasil penelitian ini dapat direkomendasikan bahwa model pembelajaran Sains Teknologi Masyarakat dapat digunakan sebagai model pembelajaran untuk meningkatkan keterampilan berpikir kreatif siswa.
\end{abstract}

Kata kunci : Sains teknologi masyarakat, keterampilan berpikir kreatif.

\section{A. PENDAHULUAN}

Ilmu pengetahuan tidak bersifat statis tetapi mengikuti perkembangan zaman. IImu pengetahuan alam adalah salah satu mata pelajaran yang dipelajari di sekolah dasar. Depdiknas (dalam Mulyasa, 2011, hlm. 110) "Ilmu pengetahuan alam diperlukan manusia untuk diperlukan dalam kehidupan sehari-hari untuk memenuhi kebutuhan manusia melalui pemecahan masalah-masalah yang dapat dikategorikan". Dalam hal ini siswa sekolah dasar perlu diberikan pembelajaran yang menerapkan sains, lingkungan, teknologi dan masayarakat yang bertujuan untuk membimbing dan mengarahkan siswa untuk merancang dan membuat suatu karya yang di dasari dari konsep IPA yang dapat digunakan untuk memcahkan masalah yang terjadi di lingkungan siswa.

Penerapan IPA harus dilakukan secara benar agar tidak berdampak buruk terhadap lingkungan serta adanya penggunaan sains yang berkaitan dengan lingkungan, teknologi dan masyarakat yang diarahkan pada pengalaman belajar siswa untuk menghasilkan suatu karya. Hal ini berkaitan dengan salah satu keterampilan yang harus dimiliki oleh siswa yaitu keterampilan untuk berpikir kreatif.

Menurut Munandar (dalam Sulaeman, 2011, hlm. 14) "Kreativitas merupakan 
kemampuan untuk menghasilkan ide-ide baru dengan cara mebuat kombinasi, membuat perubahan, atau mengaplikasikan ide-ide yang ada pada wilayah yang berbeda". Dapat diartikan bahwa berpikir kreatif adalah aktivitas berpikir agar muncul kreativitas pada seseorang, atau berpikir untuk menghasilkan hal yang baru bagi dirinya. Dalam penelitian ini, peneliti menggunakan lima indikator yang dikemukakan oleh Sulaeman (2016, hlm. 15-16) yaitu terdapat lima indikator keterampilan berpikir kreatif, diantaranya adalah 1) keterampilan berpikir lancar (fluency) ; 2) keterampilan berpikir luwes (flexibility); 3) keterampilan berpikir orisinil (Originality); 4) keterampilan berpikir merinci (elaboration); 5) keterampilan berpikir mengevaluasi (evaluation).

Berdasarkan hasil observasi, uji instrument soal keterampilan berpikir kreatif dan wawancara guru kelas VB SDN Cikampek Timur I menunjukan rata-rata siswa kelas VB SDN Cikampek Timur I termasuk dalam siswa yang memiliki keterampilan berfikir kreatif tergolong rendah. Hal ini dibuktikan dengan pengujian instrumen berbentuk soal yang meliputi lima indikator berfikir kreatif, rata-rata siswa tidak dapat mengungkapkan berbagai macam gagasan dan ide untuk memecahkan masalah yang terjadi di lingkungan sekitar siswa, terdapat beberapa faktor yang menyebabkan kemampuan berpikir kreatif siswa tergolong rendah, diantaranya karena tidak ada dorongan kepada siswa untuk mengungkapkan berbagai gagasan serta memberikan suatu solusi untuk suatu masalah serta siswa tidak dituntut untuk membuat suatu karya yang nyata untuk pemecahan masalah yang terjadi di lingkungannya.

Menurut Poedjiadi (2010, hlm. 124) "Model Sains Teknologi Masyarakat (STM) mengembangkan kemampuan kognitif, afektif dan psikomotor yang dibentuk dalam diri siswa, dengan tujuan dapat diterapkan dalaam kehidupan sehari-hari”. Poedjiadi (2010, hlm. 126) "Kekhasan dari model Sains Teknologi Masyarakat (STM) adalah pada tahap pendahuluan dengan dikemukakan isu-isu atau masalah yang ada di masyarakat yang dapat digali dari individu". Beranjak dari isu-isu atau masalah yang terjadi di masyarakat, siswa didorong untuk mengembangkan keterampilannya untuk memecahkan masalah tersebut dan dapat diaplikasikan pada kehidupan seharihari. Tujuan dari model pembelajaran Sains Teknologi Masyarakat (STM) menurut Widodo (2007, hlm. 62) "menjadikan individu peduli pada lingkungan sekitar dan peduli pada isu-isu yang berkembang di lingkungannya serta mampu mengatasi isuisu tersebut dengan menerapkan pengetahuannya". Penerapan model Sains Teknologi Masyarakat (STM) sangat diperlukan siswa sekolah dasar untuk menerapkan sejak dini sikap peduli terhadap lingkungan dan mampu mengatasi masalah yang yerjadi di lingkungannya dengan menerapkan pengetahuan yang telah dimilikinya.

Dalam penerapan model Sains Teknologi Masyarakat (STM) dengan tujuan untuk meningkatkan keterampilan berpikir kreatiif mencakup lima fase atau tahapan menurut Poedjadi (2010, hlm. 126) "tahap apersepsi, tahap pembentukan konsep, tahap aplikasi konsep atau penyelesaian masalah, tahap pemantapan konsep, dan tahap evaluasi". Peneliti menggunakan instrument soal yang digunakan untuk mengukur peningkatan keterampilan berpikir kreatif dengan lima indikator. Dari kelima indikator tersebut peneliti membuat instrimen soal yang di dalamnya mencakup kelima indikator keterampilan berpikir tersebut dengan mengacu kepada indikator pembelajaran dan jenjang kognitif yang dikemukakan oleh Taksonomi Bloom yang mencakup C2 sampai C5.

Berdasarkan uraian di atas perlu dikaji lebih jauh mengenai model pembelajaran Sains Teknologi Masyarakat (STM) terhadap peningkatan keterampilan berpikir kreatif siswa sekolah dasar. Dalam penelitian ini peneliti membahas hal-hal yang terjadi dalam kehidupan sehari-hari yang dapat menumbuhkan sikap peduli dan tanggap tehadap isu-isu atau masalah yang berkembang di masyarakat dengan 
mengaplikasikan pengetahuan yang telah dimilikinya.

\section{B. METODE}

Metode penelitian yang digunakan dalam penelitian ini adalah penelitian tindakan kelas. Menurut Carr dan Kemmis (dalam Kusumah dan Dwitagama, 2012, hlm. 8) "Penelitian tindakan kelas adalah suatu bentuk penelitian refleksi diri (self reflective) yang dilakukan oleh para partisipan dalam situasi sosial untuk memperbaiki rasionalitas dan kebenaran". Dari pemaparan tersebut penelitian tindakan kelas ini dilakukan oleh peneliti yang berperan sebagai guru dalam upaya untuk memperbaiki pembelajaran sehingga menghasilkan perubahan yang lebih baik dalam hasil pembelajaran yang dilakukan oleh siswa.

Dalam penelitian tindakan kelas ini peneliti menggunakan desain penelitian yang dikemukakan oleh Kemmis dan McTaggart (dalam Kusumah dan Dwitagma, 2012, hlm. 20-21) mengemukakan bahwa "komponen penelitian tindakan kelas mencakup perencanaan, tindakan, pengamatan dan refleksi".

Penelitian tindakan kelas ini dilakukan pada kelas VB SDN Cikampek Timur I dengan jumlah subjek penelitian 20 siswa yang terdiri dari 11 siswa perempuan dan 9 siswa laki-laki. Dalam pelaksanaan penelitian perlu adanya instrument penelitian, menurut Sugiyono (2015, hlm. 191) mengemukakan bahwa "instrumen dalam penelitian tindakan digunakan untuk mengumpulkan data sebelum ada tindakan (pretest), selama tindakan (proses pelaksanaan tindakan) dan setelah ada tindakan (posttest)". Dalam penelitian ini terdapat dua instrumen penelitian yaitu tes untuk mengumpulkan data sebelum ada tindakan (pretest) dan setelah ada tindakan (posttest) untuk mengukur peningkatan keterampilan berpikir kreatif dan observasi untuk megumpulkan data selama tindakan atau selama proses pelaksanaan tindakan.

Instrument yang digunakan dalam penelitian ini adalah tes dan observasi. Tes keterampilan berpikir kreatif diperlukan untuk memperoleh data mengenai peningkatan keterampilan berpikir kreatif siswa kelas VB SDN CIKAMPEK TIMUR I yang telah disampaikan dalam pembelajaran, keterampilan berpikir kreatif siswa dapat dilihat dari ketuntasan belejar peserta didik setelah pembelajaran. Observasi sebagai alat pengumpulan data selama tindakan (proses tindakan).

Soal tes keterampilan berpikir kreatif dibuat dalam bentuk isian (essay) sebanyak 15 soal dengan pembagian 5 soal di setiap siklusnya. Soal tes yang dibuat berpedoman pada 5 indikator keterampilan berpikir kreatif meliputi 1) keterampilan berpikir lancar (fluency) ; 2) keterampilan berpikir luwes (flexibility); 3) keterampilan berpikir orisinil (Originality); 4) keterampilan berpikir merinci (elaboration); 5)keterampilan berpikir mengevaluasi (evaluation) serta jenjang kognitif Taksonomi Bloom (C2 sampai C5).

Penskoran dalam tes keterampilan berpikir kreatif didasarkan pada panduan penskoran dengan menggunakan skala Likert yakni dengan kategori skor 1-4 dengan kategori yang berbeda disetiap perolehan skornya.

Menurut Sugiyono (2011, hlm. 135) Penskoran dengan skala Likert dapat menggunakan kategori sebagai berikut:

1 = Sangat Tidak Baik

2 = Tidak Baik

3 = Baik

4 = Sangat Baik

Menurut Sugiyono (2014, hlm.308) mengemukakan bahwa "teknik pengumpulan data merupakan langkah yang paling utama dalam penelitian, karena tujuan utama penelitian adalah mendapatkan data". Teknik pengumpulan data yang digunakan dalam penelitian ini adalah observasi dan dokumntasi.

Observasi yang dilakukan dalam penelitian ini adalah observasi partisipatif. Menurut Stainback, S (dalam Sugiyono, 2014, hlm. 311) mengemukakan bahwa "dalam observasi partisipatif, peneliti mengamati apa yang dikerjakan orang, mendengarkan apa yang mereka ucapkan, dan berpartisipasi dalam aktivitas mereka". 
Dari pemaparan tersebut, peneliti menggunakan observasi partisipatif dengan tujuan mengamati aktivitas belajar siswa dan aktivitas mengajar peneliti yang berperan sebagai guru.

Menurut Sugiyono (2014, hlm. 326) mengemukakan bahwa "dokumen merupakan catatan peristiwa yang sudah berlalu". Dokumentasi yang digunakan dalam penelitian ini mencakup berkas yang berkaitan dengan penelitian dan foto-foto ketika dilaksanakannya penelitian menggunakan model pembelajaran STM (Sains Teknologi Masyarakat (STM)).

Analisis data pada penelitian ini adalah mengenai bagaimana cara mengetahui hasil peningkatan keterampilan berpikir kreatif siswa SDN CIKAMPEK TIMUR I dengan cara menghitung data yang telah diperoleh pada saat penerapan siklus penelitian tindakan kelas. Data yang dapat diukur atau dihitung ialah hasil belajar yang mengacu pada indikator keterampilan berpikir kreatif. Menurut Trianto (2012, hlm. 63) "Dalam menentukan ketuntasan belajar siswa digunakan instrumen tes yang meliputi produk, proses dan psikomotor".

\section{HASIL PENELITIAN DAN PEMBAHASAN}

Penelitinan tindakan kelas yang dilakukan dalam penelitian ini sebanyak 3 siklus. Dalam setiap pelaksanaan siklus mencakup 2 pertemuan yang dilakukan sebanyak 2 jampembelajaran dengan alokasi waktu 2x35 menit. Pada pelaksanaan siklus I dengan materi pertemuan pertama manfaat air dan pertemuan kedua daur air.

A. SIKLUS I

Data hasil perolehan posttest siklus I dengan materi manfaat air dan daur air memperoleh skor ketuntasan belajar individual 1.505, dengan rata-rata 75.25 dengan persentase ketuntasan belajar diatas KKM (70) sebanyak $75 \%$ dari 20 orang peserta didik serta rata-rata skor $N$ Gain 0.433. Jumlah peserta didik yang berhasil mencapai KKM (70) sebanyak 15 orang dari 20 orang peserta didik. Hasil perolehan nilai tertinggi dengan skor 90 dan hasil perolehan nilai terendah memperoleh skor 65.

B. SIKLUS II

Data hasil perolehan posttest siklus II dengan materi alat penyaring air sederhana memperoleh sederhana memperoleh jumlah skor ketuntasan belajar individual 1.505, dengan rata-rata 75.25 dengan persentase ketuntasan belajar diatas KKM (70) sebanyak $85 \%$ dari 20 siswa memperoleh skor rata-rata $N$-Gain 0.486 dengan kriteria sedang. Jumlah peserta didik yang berhasil mencapai KKM (70) sebanyak 17 orang peserta didik dari 20 orang peserta didik. Hasil perolehan nilai tertinggi dengan skor 85 dan hasil perolehan nilai terendah memperoleh skor 65 .

C. SIKLUS III

Data hasil perolehan posttest siklus III dengan materi kegiatan manusia yang dapat mempengaruhi daur air dan menghemat air yang diikuti oleh 20 orang siswa memperoleh jumlah skor ketuntasan belajar individual 1555, dengan rata-rata 77.75 dengan persentase ketuntasan belajar diatas KKM (70) sebanyak $90 \%$ dari 20 orang peserta didik dengan skor ratarata $N$-Gain 0.4615 dengan kriteria sedang. Jumlah peserta didik yang berhasil mencapai KKM (70) sebanyak 18 orang peserta didik dari 20 orang peserta didik. Hasil perolehan nilai tertinggi dengan skor 95 dan hasil perolehan nilai terendah memperoleh skor 65.

Dari hasil pemaparan diatas dapat disimpulkan bahwa penelitian telah dinyatakan selesai dengan dilakukannya III siklus. Hal ini dibuktikan dengan hasil kegiatan observasi guru dan siswa sudah dinyatakan berhasil karena telah mencapai persentase $90 \%$ dengan kategori sangat baik dan penelitian sudah dinyatakan berhasil dengan perolehan skor Ketuntasan Belajar Siswa Klasikal (KBSK) sudah mencapai $90 \%$ dengan kategori sangat baik.

\section{PEMBAHASAN}

Berdasarkan analisis data yang tercantum pada setiap siklusnya menunjukkan adanya peningkatan hasil dari 
keterampilan berpikir kreatif setelah kegiatan pembelajaran yang menerapkan model pembelajaran Sains Teknologi Masyarakat (STM). Keterampilan berpikir kreatif siswa kelas V SDN Cikampek Timur I pada siklus I materi manfaat air dan daur air memperoleh jumlah skor keseluruhan masih rendah dan mengalami peningkatan di siklus II dengan materi alat penyaring air sederhana dan siklus III materi kegiatan manusia yang mempengaruhi daur air dan menghemat air. Da hasil perolehan skor pretest dan posttest dapat dilihat dari ketuntasan belajar pada setiap siklusnya.

Berikut data yang dipaparkan dalam bentuk grafik, ialah:

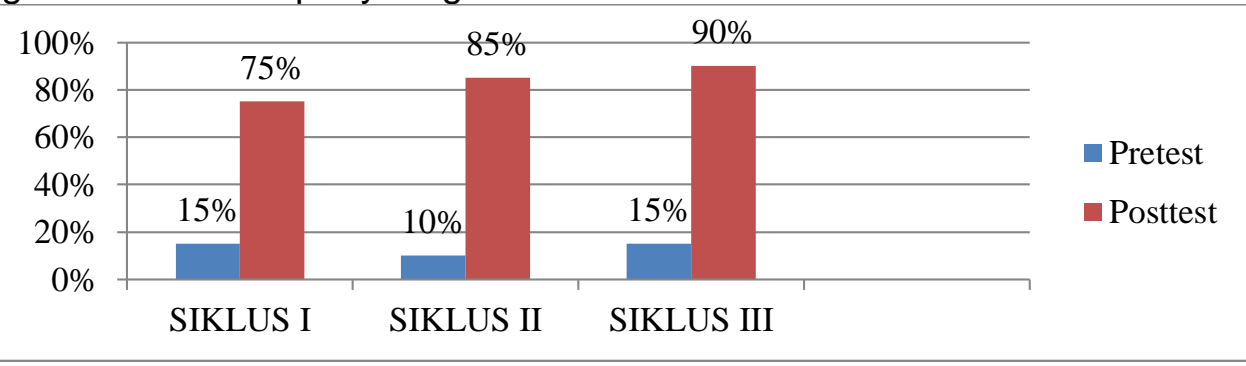

(Sumber: Hasil perolehan pretest dan posttest KBSK siklus I, II, dan III) Gambar 4.3

\section{Grafik Hasil Perolehan Pretest dan Posttest}

Ketuntasan Belajar Siswa Klasikal (KBSK)

Data tersebut sangat jelas menunjukkan bahwa adanya ketuntasan belajar siswa klasikal (KBSK) sudah melampaui $85 \%$ atau dinyatakan tuntas (Trianto, 2012, hlm. 241). Peningkatan pencapaian pada penelitian ini dilihat melalui

$$
\text { perhitungan N-Gain. }
$$

Peningkatan $\mathrm{N}$-Gain siswa didasarkan pada hasil pretest dan posttest dari setiap siklus. Nilai rata-rata perolehan $N$-Gain pada setiap siklus dapat dilihat pada Gambar 4.5

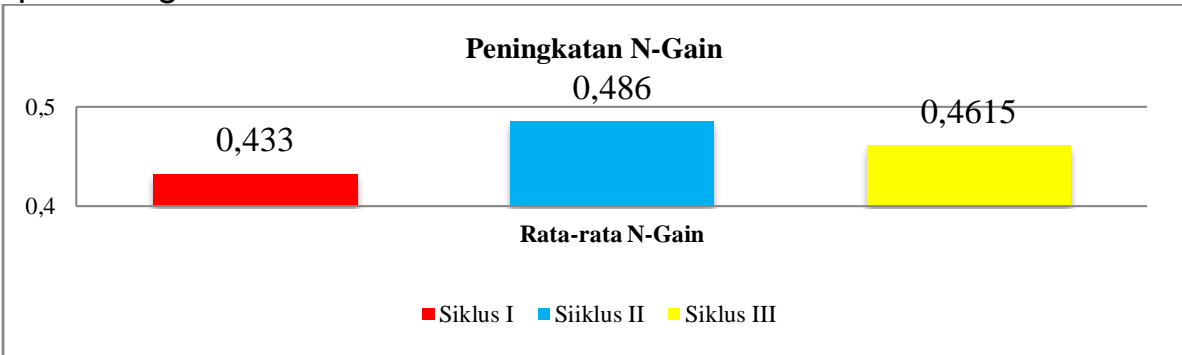

(Sumber: Hasil perolehan N-Gain siswa pada siklus I, II dan III)

Gambar 4.5

Garafik Peningkatan N-Gain

Pada Gambar 4.5 terlihat bahwa batang yang berwarna merah menunjukkan hasil perolehan rata-rata $N$-Gain pada siklus I dengan nilai 0.433 dengan kriteria sedang, pada batang yang berwarna biru menunjukkan nilai $N$-Gain siklus II yang mengalami peningkatan yang signifikan dengan nilai rata-rata $N$-Gain 0.486 kategori sedang dan pada batang yang berwarna kuning menunjukkan rata-rata nilai $N$-Gain siklus III yang memperoleh nila rata-rata $N$ -
Gain 0.4615. Berdasarkan rata-rata perolehan nilai $\mathrm{N}$-Gain pada siklus I, II dan III dapat disimpulkan bahwa peningkatan keterampilan berpikir kreatif siswa pada kelas VB SDN Cikampek Timur I tergolong pada kategori sedang.

Dari pemaparan di atas membuktikan bahwa adanya peningkatan persentase Ketuntasan Belajar Siswa Klasikal (KBSK) pada setiap siklus setelah dilakukannya pembelajaran dengan model Sains 
Teknologi Masyarakat (STM) sehingga dapat mencapai Ketuntasan Belajar Siswa Klasikal (KBSK) 90\%. Maka dapat disimpulkan bahwa dengan penerapan model pembelajaran Sains Teknologi Masyarakat (STM) dapat meningkatkan keterampilan berpikir kreatif siswa kelas VB SDN Cikampek Timur I.

\section{E. SIMPULAN DAN SARAN}

Berdasakan hasil temuan dan pembahasan penelitian, maka dapat disimpulkan bahwa:

1. Dengan penerapan model pembelajaran STM (ains Teknologi Masayarakat) aktivitas belajar siswa dalam pembelajaran IPA secara bertahap mengalami peningkatan. Pada siklus I, aktivitas siswa memperoleh persentase $79.18 \%$ dengan kategori baik, kemudian mengalami peningkatan pada siklus II memperoleh persentase $82 \%$ dengan kategori baik, dan terus mengalami peningkatan yang signifikan pada siklus III dengan perolehan persentase $90 \%$ dengan kategori sangat baik. Hal ini membuktikan bahwa dengan diterampkannya model pembelajaran STM (Sains Teknologi Masayarakat) pada pembelajaran IPA dapat meningkatkan aktivitas belajar siswa dan antusiasme siswa VB SDN Cikampek Timur I.

2. Berdasarkan hasil data yang diperoleh sebelum dilakukannya pembelajaran dengan menerapkan model pembelajaran STM (Sains Teknologi Masayarakat) (pretest), rata-rata perolehan skor pretest siswa masih rendah, dengan dilakukannya pembelajaran yang menerapkan model pembelajaran Sains Teknologi Masyarakat (STM) perolehan skor ratarata postest siswa kelas VB SDN Cikampek Timur I mengalami peningkatan. Pada siklus I memperoleh persentase $75 \%$ dengan perolehan nilai tertinggi 90 dan nilai terendah 65 dengan jumlah 15 siswa yang telah mencapai KKM (70), kemudian setelah dilaksanakannya siklus II mengalami peningkatan persentase yang signifikan dengan perolehan persentase $85 \%$ dengan perolehan nilai tertinggi 85 dan nilai terendah 65 dengan jumlah 17 siswa yang telah mencapai KKM (70), kemudian pada siklus III terus mengalami peningkatan yang signifikan dengan perolehan persentase 90\% dengan perolehan nilai tertinggi 95 dan nilai terendah 65 dengan jumlah 18 siswa yang telah mencapai KKM (70). Berdasarkan rata-rata perolehan nilai $N$ Gain pada siklus I, II dan III dapat disimpulkan bahwa peningkatan keterampilan berpikir kreatif siswa pada kelas VB SDN Cikampek Timur I tergolong pada kategori sedang.

Dalam pelaksanaan dengan menerapkan model pembelajaran Sains Teknologi Masyarakat (STM) sebaiknya penelitian selanjutnya mempersiapkan waktu lebih banyak dalam menggunakan model ini, karena dalam setiap tahapan atau fase dalam model ini perlu adanya pengkajian materi lebih dalam sehingga siswa lebih memahami materi yang disampaikan dan dapat mencapai tujuan pembelajaran yang telah ditentukan.

\section{DAFTAR RUJUKAN}

Kusumah, W., \& Dwitagma, D. (2012). Mengenal Penelitian Tindakan Kelas. Jakarta: Indeks.

Mulyasa, E. (2011). Kurikulum Tingkat Satuan Pendidikan. Bandung: PT Remaja Rosdakarya.

Poedjiadi, A. (2010). Sains Teknologi Masyarakat. Bandung:PT Remaja Rosdakarya Offset.

Sugiyono. (2011). Metode Penelitian Pendidikan. Bandung: ALFABETA.

Sugiyono. (2014). Metode Penelitian Kombinasi (Mixed Methods).

Bandung: ALFABETA.

Sugiyono. (2015). Metode Penelitian Tindakan Komprehensif. Bandung: ALFABETA.

Sulaeman, M. (2016). Aplikasi Project Based Learning (APBL) untuk Membangun Keterampilan Berpikir Kritis dan Kreatif Siswa (MKBKKS). Depok, Jawa Barat:Bioma. 
Trianto. (2012). Panduan Lengkap Penelitian Tindakan Kelas (Classroom Action Research) Teori dan Praktik. Jakarta: Prestasi Pustaka Raya.

Widodo, A., Wuryastuti, S., \& Margaretha. (2007). Pendidikan IPA di SD. Bandung: UPI PRESS. 